Environment Conservation Journal 14(1\&2) 61-64 , 2013

ISSN 0972-3099 (Print) 2278-5124 (Online)

Abstracted and Indexed

\title{
Scope and reason of travel in accordance with Maslow's hierarchy of needs
}

\author{
Ram Shrivastava and Manish Nagaich $\bowtie$
}

Received: 08.08.2012

Revised: 15.10.2012

Accepted: 6.03.2013

\begin{abstract}
This paper examines the need and necessity of travel of people to satisfy all the levels of need which are bracketed in various five levels of hierarchy of needs namely physiological needs, safety and security needs, love and belonging need, self-esteem needs and the need of self-actualization of Maslow's.
\end{abstract}

\section{Introduction}

A dark cold night which was spreaded over the kingdom of Magadh dynasty of king Shuddhodhana, The royal prince Siddhartha the son of Shuddhodana was still awaken and walking in the courtyard just adjacent to his grand and glittered room in the royal palace, with a storm within which was ordering him to leave the world. The sleepiness was thousands of miles away from his eyes, who were desperately been activated because of an incident happened yesterevening and were stimulated for the search of God.In the last hours of night, Siddhartha came back to his room; put off all the glamorous article from his body and with the simplest material of clothing he wraped himself and moved towards the bed where his wife Yashoddhara and his beloved child, aged just few months, Rahul were sleeping deeply. An unmatched innocent beauty of his wife and most innocent toy like expressions of his son tried and compelled him to stop for what he had decided to do. He reached closer to the bed, gave a deep glance to both History of India (2002). He then put his soft palm on the cheeks of his son, who suddenly smiled in the sleep itself. Siddhartha left the room at once before he could be arrested from the innocency of his son and moved fast towards the rooms of his father, he also had to rush on the doors of his mother's Mahapajapati room too, who brought Siddhartha up after his mother, queen Maya. He bowed his forehead on the entrance of both's of their rooms and left everything then and

\section{Author's Address}

Agra Public College of Technology and Management, Agra E-mail: manish.nagaich@gmail.com

Copyright by ASEA

All rights of reproduction in any form reserved there. Thus he moved away for the search of his MahaNirwana (ultimate wisdom) (Etzel et al. 1998).Later on this royal prince of Shakya Dynasty, who was known as a Siddhartha got selfactualization and became known to the world as Buddha. The Enlightened Buddha This part of the story has been taken up from the life of Buddha, who travelled from the capital of his kingdom to various places of the country. He travelled in the search of truth as he believed that the truth is the real form of the God. He travelled for miles and miles from one place to another he travelled.

\section{Objective of the study}

The objective of the study is to identify the role of tourism in the satisfaction of needs of all five levels in Maslow's hierarchy of needs. We will try here to fetch out the importance of travel in the life of people by which they satisfy their various needs.

\section{Study site}

As such no geographical site has been witnessed for the study, but we have taken secondary data in the form of the various parts of ancient, medieval and modern history of India along with the current trends which are been directing society to move from Indian Sub-continental.

\section{Study}

People in the World; have got a unique feature as an urge for knowing the world around. This urge is known as curiosity. This urge takes different and various shapes which can commonly be named as need, want, desire and passion. These needs, wants, 
desires and passion give them a drive to move in the direction where they can be satisfied, or they can chase them with all devotion. Hence at times this curiosity becomes need, want, desire and passion, if discovered or explored properly.

Can we imagine a World without no need of travelling ever Perhaps not! This travelling activity in modified form, known as tourism. Let's take a glance on the concept and definition of tourism. The world tourism has been derived from the Latin word 'Tournos', which means 'To Move'. According to WTO, "tourism is an activity in which a person moves to a place other than his normal place of domicile for than 24 hours and less than 365 days without indulging in any remuneration activity". A person who exercises this activity is known as tourist. In the same way a travel of less than $50 \mathrm{kms}$ and less than 24 hours is known as 'excursion' and a person involved in it is known as 'Excursionist'.By the time and further development, every motive of travel is been categorized specifically and nomenclatured with a particular tag. Such as business tourism, agro tourism, medical tourism, health tourism, cultural tourism, green tourism etc.Abraham Harold Maslow a great behavioral scientist and the pioneer of humanistic psychology from 1908 to 1970 Wisconsin University USA proposed through his theory in1943 in his book Motivation and personality. He proposed a hierarchy of needs with the five layers in pyramidal form. On the bottom physiological needs which are known as Basic needs were placed and then safety and security, love and belonging, self-esteem and selfactualization needs were put respectively in the pyramid.

\section{Physiological needs}

Physiological needs are known as basic needs and compels for the satisfaction of hunger, thirst, sleep and shelter.

\section{Safety and security needs}

A safety and security need refers to the financial back up like savings, owning a house and all the tools which are helpful to protect against barriers to life.

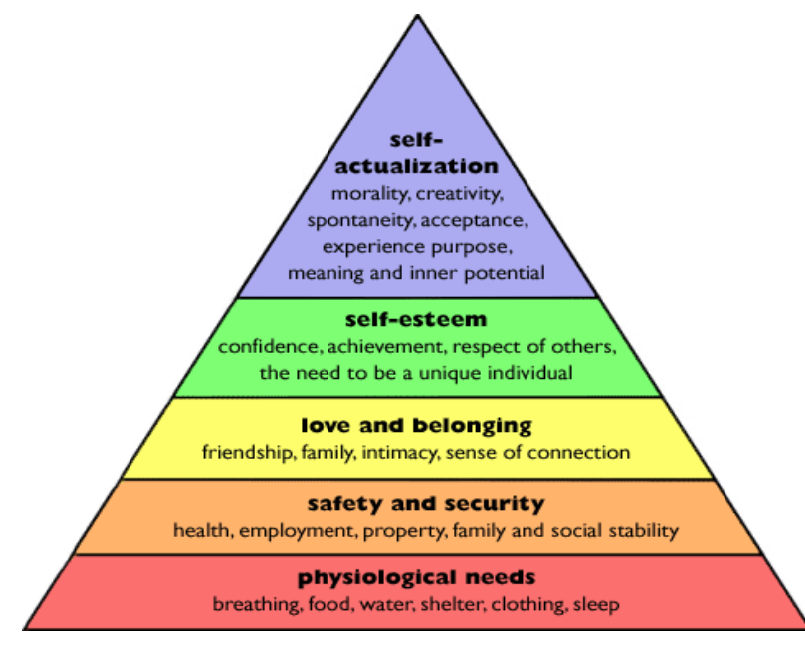

\section{Maslow’s hierarchy of needs}

\section{Love and belonging needs}

Love and belonging need refers to the belongingness of an individual with his peers, family and other groups, where his identity can be retained.

\section{Self-esteem needs}

Here the need of showing self-confidence, selfcontrol, receiving award, reward, respect, recognition and appreciation occurs and people strive to get motivated in this direction only.

\section{Self-actualization}

The utmost exploration of self-potential, Maslow describe it "what one can be, he must be". Here the person becomes the ultimate in his concern had. Since the past we see that people's life do evolve as per the layers of hierarchy of needs. From the arrangements of their food to their self-exploration they are motivated accordingly and try to gratify their needs.Very interestingly, travel has got a unique characteristic, which satisfies various needs in various ways. How a person satisfies their various (all five level needs) with the help of travel? We will try to study it here, for which we will have a glance from the ventilation of history and would travel in the street of current era. Hence we would find the various aspects of travel and its 
dynamism to satisfy the need of people in their life time Luthansfred (2000), Carthy and Perrlault (1998).In the Stone Age, where our ancestor used to survive like a beast, are to be quoted here as we have read about them that they never had a home or permanent shelter, they used to had their food in the form of leaves, fruits and other vegetation along with the meat and flash of other animals. In the search of food and shelter he used to wander one place to another and thus could be able to survive against anti-temperature and hunger. Under the open sky, caves, dwellings, tree branches used to be his place of shelter where he could rest while felt fatigue.As soon as his body used to get re-energized with rest and sleep, he used to take a new start for another place to search for the food. This of his movements could occurred on the basis of seasons or climatic conditions. The survival story of early men can be longer but here we can count his movement from one place to another in search of food and shelter, as the inception of travel or an origination of travel. We cannot deny here for the fact that this travel of early men was motivated from the physiological needs. Hence a travel for physiological needs can be recorded and marked here (Batra and Kazmi, 2001). If we take a glance in the medieval history, we see Indians were trading Trans world, the silk route was meant for business purposes for business men. This route had a remarkable number of travellers, who were to move Trans world for the sake of livelihood. The first freedom fight in 1857 by Indian against 'the British rule' where the armies of Indian rulers moved from one to another place, even we read from the history books that the army of the king moved to fight against enemies. These instances certainly indicate for the issues of safety and security in terms of financial back-up, safe surroundings and fearless environment. All the above quoted movements can clearly be spotted as the travel for safety and security needs.As and when it comes to love and Belongingness needs, which are also known as social needs, Mutual relations of each other for which people go from one place to another to satisfy their emotions. V.F.R (visiting friends and relatives) tourism denotes this - the examples for the satisfaction of this need can be viewed from the lives of general public, where they go to attend the social gatherings like marriage, holy occasions and others. Pilgrimage travel for the Kumbh is also an example of the satisfaction of social or love and belongingness needs. The marriage of Akbar the great with princess Jodha Bai can be traced as the satisfaction of his social needs, where he went to Jaipur with a proposal of marriage to the father of this princess History of India (2002) and Carthyand Perrlault (1998). For the sake of self-esteem needs Alexender the great travelled over the earth to conquer the earth. Our Indian mythology also speaks about the concept of Chakravarti Samrat (a king who rules over the globe). Here this is noticeable that to became the king of the world requires to do travel a lot to win the world geographically. Same did Alexander the great and other Chakravarti Samrat, who travelled from one place to another place to satisfy their self-esteem needs. Where as self-actualization attainment could also be acquired by the people through travel, again Siddhartha left home and wondered for the enlightenment at various places. He journey from Siddhartha to Buddha was supported with his travel. Dandi march of Gandhi, which is known as salt journey is one of the remarkable task of his life time. Migration of mother Teresa from her home country to India can be illustrated as a journey for self-actualization History of India (2002). Similarly in modern times, people move from one place to another for the sake of livelihood. A lot of unskilled labor move from country side to urban regions for the sake of bread and butter. Though money is a bigger motivating factor for them but travel is primarily required to acquire that money.Everyone wants a safer and secured environment to survive; we see lots of people are migrating from the terrorism prone area to the safer three, two or one tier cities. Migration from backward or underdeveloped regions to the places which offers safer and secured life conditions in terms of financial backupand anti-barrier environment denote the inherency of the phenomenon of travel where they will meet out with second level needs with the help of travel only. We see a high domestic internal transfers of the people for the satisfaction of social or love and belongingness needs. 
When people go to meet their family and friends its known as V.F.R (visiting friends and relative) tourism. According to the I.T.D.C census 2010 total of $43.49 \%$ of domestic tourism was dedicated to V.F.R tourism. Here we see a tremendous expressive behavior of people for the satisfaction of social need by travels. Esteem needs are easy to satisfy by the travel, as it is reflected from opting the mode and quality of transportation. We see more crises in acquiring a berth in air-conditioned coach of a train instead of non-air-conditioned coach (Luthansfred, 2000). The popularity of air travel and cruise lines can be deemed as the mode and tool of the satisfaction of esteem needs. As its said by Maslow's about self-actualization, "what a man can be, he must be". Those religious saints like Dalai Lama, Pop, Shankracharya, other iconic artist - Actors, musicians, painters, move from one place to another for the gratification of the need of selfactualization to explore their inner-self at fullest. The moves of Phylenthropist like Bill Gates in the various regions of the world to share trouble and pathetichess, we see importantly the need of travel in this level. Aone important phenomenon we see how the travel is fused with in the hierarchy of Maslow.

\section{Result and Discussion}

With above study we see that in many of the cases, people travel for a distance whether short or long for the satisfaction of their basic, safety and security, love and belongingness, self-esteem and self-actualization needs from the history and current era and see that the travel is an extended tool for the gratification of any kind of need.

\section{Conclusion}

We can obviously say that be it any kind of need like food, money, physical safety, social, esteem or to explore own potential, travel is probably sure to occur for the execution of satisfaction of that need, we have discussed it in study with various examples. Hence we can say the role and importance of travel can not be neglected in fulfilling the various needs of human.

\section{Acknowledgement}

Authors are highly thankful to Dr. Vikrant Shastri, Director U.I.M.S Agra, for his valuable and moral boosting during the writing of article. We would be failed in our duties if we won't express our gratitude to Dr. U.N Shukla, Lecturer in Deptt of Tourism ITHM, Khandari Agra, who has given valuable suggestion in this study. Dr R. B. Singh Agra University and Dr A.K Singh My Colleague for moral upliftment during the study.

\section{References}

History of India 2002. Dr Ashirvadilal (Pearson Education $13^{\text {th }}$ edition)

Etzel M.J., Walker B.J. and Stanton William J. 1998 Marketing Concept and cases special Indian edition (Tata McGraw Hill $13^{\text {th }}$ edition)

Luthansfred 2000 Organisational Behavior (Tata McGraw Hill $10^{\text {th }}$ edition)

Carthy\&Perrlault 1998 Basic Marketing A Global Marketing Approach (Tata McGraw Hill $15^{\text {th }}$ edition)

Satish k Batra and S H HKazmi 2001 Consumer behavior Text and cases, Excel Books ( $2^{\text {nd }}$ Edition) 